\title{
Studi Implementasi Digital Marketing Pada Pengusaha Di Semarang
}

\author{
Maria Yosephine Dwi Hayu Agustini' ${ }^{1}$; Sentot Suciarto Athanasius ${ }^{2}$; \\ Berta Bekti Retnawati ${ }^{3}$; Antonius Haryo Perwito ${ }^{4}$; Dyah Titisari Anugraheni ${ }^{5}$ \\ Email Korespondensi: 'hayu@unika.ac.id \\ Universitas Katolik Soegijapranata
}

\begin{abstract}
The application of digital marketing is increasingly widespread and has been applied by many entrepreneurs as a strategy to enter or expand the market. Entrepreneurs can choose ways and forms of digital marketing that suit the characteristics of their businesses and consumers. This study is intended to determine how far the level of digital marketing implementation for entrepreneurs in the city and district of Semarang. The study used a sample of 30 entrepreneurs who had implemented digital marketing and were selected using convenient sampling. Data were collected by questionnaires that were delivered in person or by email and processed with descriptive statistics to be analyzed using descriptive methods. The results show that the implementation of digital marketing is quite high. This means that entrepreneurs have used digital facilities (internet) in all their marketing activities, which include the delivery of product and business information, product ordering facilities, delivery of payment method options and delivery services. In the future, research can be focused on understanding online buying behavior that can be utilized by entrepreneurs in determining the right marketing strategy.
\end{abstract}

Keywords : digital marketing; marketing strategy; online promotion.

\section{PENDAHULUAN}

Perkembangan penggunaan internet telah mengubah cara berinteraksi antara konsumen dan pemasar secara drastis. Banyak perusahaan besar maupun kecil dan mikro telah memanfaatkan internet untuk memasarkan produk mereka mereka secara online untuk menjangkau konsumennya atau menerapkan digital marketing sebagai cara untuk menyampaikan nilai lebih kepada target konsumen (Kannan \& Li, 2015) mengingat konsumen memiliki pandangan yang sudah berbeda tentang kenyamanan, kecepatan, harga, informasi produk, dan pelayanan karena internet (Kotler \& Armstrong, 2014).

Di sisi lain, kepercayaan konsumen terhadap digital marketing semakin besar. Sebuah infografis menunjukkan bahwa tingkat kepercayaan konsumen di kawasan Asia Tenggara pada digital marketing sudah mencapai lebih dari 50\% 
JEMAP: Jurnal Ekonomi, Manajemen, Akuntansi, dan Perpajakan

ISSN: 2622-612X (Media Online) | Vol.4 | No.2 | Oktober 2021

(Busines2Community.com, 2019). Tingkat kepercayaan konsumen tertinggi ada pada iklan di search engine yang mencapai 57\%. Kemudian diikuti media sosial $(53 \%)$ dan iklan video online (52\%). Sedangkan tingkat kepercayaan terhadap banner online hanya sebesar $47 \%$. Kondisi ini mengindikasikan potensi yang besar untuk mengimplementasikan digital marketing.

Pengusaha maupun konsumen merasakan manfaat dari implementasi digital marketing. Bagi pengusaha, implementasi digital marketing memungkinkan mereka dapat terhubung dengan konsumen secara lebih dekat dan dapat melayani konsumen secara real-time, meningkatkan penjualan, menghemat biaya pemasaran, meningkatkan pendapatan, dan memperluas pasar (Gunarto, 2019). Di sisi lain, konsumen merasakan lebih nyaman, mudah, dan bersifat lebih privasi ketika bertransaksi secara online (Kotler \& Armstrong, 2014). Mereka bisa berbelanja secara online tanpa batasan waktu dan tempat.

Dalam implementasi digital marketing, pengusaha mengkombinasikan beberapa cara, seperti website, iklan dan promosi online, social media marketing, e-mail marketing, dan mobile marketing (Kotler \& Armstrong, 2014), untuk bisa mencapai konsumen dengan cara yang paling efektif dan efisien. Namun tidak ada cara terbaik yang berlaku secara umum untuk semua pengusaha. Pada dasarnya, cara yang efektif dan efisien terjadi ketika apa yang ingin disampaikan atau ditawarkan pengusaha kepada konsumen dapat ditangkap dan dipersepsikan secara sama oleh konsumen melalui media yang dapat menjangkau konsumen sasaran. Oleh karena itu, implementasi digital marketing bervariasi antara satu perusahaan dengan perusahaan lain.

Penelitian ini membahas tentang sejauh mana tingkat implementasi digital marketing oleh pengusaha. Menurut AMA, digital marketing adalah aktivitas, pengorganisasian, dan pemrosesan yang difasilitasi dengan teknologi digital pada penciptaan, pengkomunikasian, dan penghantaran nilai pada konsumen dan para pemangku kepentingan (American Marketing Association, 2019). Mengacu pada pengertian tersebut, tingkat implementasi oleh pengusaha ditinjau dari kegiatan pemasaran yang difasilitasi dengan teknologi digital pada penciptaan, pengkomunikasian, dan penghantaran nilai pada konsumen. Tingkat implementasi 
JEMAP: Jurnal Ekonomi, Manajemen, Akuntansi, dan Perpajakan

ISSN: 2622-612X (Media Online) | Vol.4 | No.2 | Oktober 2021

tinggi apabila pengusaha sudah melakukan hal-hal tersebut sepenuhnya dengan menggunakan fasilitas digital (internet), dan sebaliknya.

Secara praktis, hasil penelitian dapat dimanfaatkan oleh para pengusaha untuk menentukan strategi pemasaran terkait dengan tingkat implementasi digital marketing yang sesuai dengan usaha dan kebutuhan konsumen. Secara konseptual, hasil ini dapat meningkatkan pemahaman tentang perilaku pembelian konsumen dan strategi pemasaran dalam konteks digital marketing yang mungkin berbeda dari konteks pemasaran biasa.

\section{TINJAUAN PUSTAKA}

\section{Pengertian dan Cakupan Digital Marketing}

Cakupan digital marketing telah mengalami perkembangan yang besar. Pada mulanya, digital marketing mencakup pemasaran barang dan jasa dengan menggunakan saluran digital. Dalam perkembangannya, digital marketing mencakup bidang yang lebih luas yaitu tentang penggunaan teknologi digital untuk mendapatkan pelanggan dan membangun preferensi yang baik bagi pelanggan, menjaga citra merek, upaya mempertahankan pelanggan, dan meningkatkan volume penjualan (Kannan \& Li, 2015).

Digital marketing mencakup pemasaran interaktif dan terpadu yang memudahkan interaksi antara produsen, perantara, dan konsumen. Di satu sisi, digital marketing memudahkan pengusaha memantau dan menyediakan produk yang sesuai dengan keinginan dan kebutuhan calon konsumen. Di sisi lain, konsumen bisa mencari dan mendapatkan informasi tentang produk dengan mudah hanya dengan mengakses atau browsing melalui internet pada waktu dan tempat sesuai keinginan.

Digital marketing mencakup B2B, B2C, C2C, dan C2B. Di dalam B2B, bisnis-bisnis saling bertemu dan berinteraksi di electronic marketplaces untuk melakukan pertukaran dan saling menjalin hubungan (hubs). Dalam electronic B2B marketplaces, sebuah bisnis yang bertindak sebagai suplier utama menciptakan 
JEMAP: Jurnal Ekonomi, Manajemen, Akuntansi, dan Perpajakan

ISSN: 2622-612X (Media Online) | Vol.4 | No.2 | Oktober 2021

portal yang digunakan untuk mengelola semua aspek pembelian dari bisnis lain dikenal dengan istilah private B2B exchanges. Dalam B2C, sebuah bisnis menjual produk kepada konsumen akhir dimana konsumen dapat secara aktif memilih site online dan mengontrol kontak tentang shopping apps yang akan digunakan, informasi yang ingin diterima atas suatu produk (Kotler \& Armstrong, 2014). Di dalam $\mathrm{C} 2 \mathrm{C}$, konsumen yang satu membeli atau mempertukarkan suatu produk atau informasi secara langsung dengan konsumen lainnya, baik untuk tujuan komersial maupun non-komersial melalui web logs atau blog. Sedangkan dalam C2B, konsumen berkomunikasi dengan pengusaha secara lebih mudah melalui internet. Pengusaha dapat mengundang konsumen untuk menyampaikan pemikiran atau pertanyaan dan konsumen dapat menghubungi perusahaan untuk bertanya, menyampaikan keluhan dan saran kepada perusahaan (Kotler \& Armstrong, 2014).

\section{Konsep Digital Marketing}

Teknologi digital telah merombak interaksi yang melibatkan aspek 5C: customers, collaborators, competitors, context, and company (Kannan \& Li, 2015) dan hal ini membutuhkan cara pengelolaan strategi pemasaran yang berbeda pula. Perubahan interaksi dimulai dari perubahan perilaku konsumen sebagai hasil dari akses ke berbagai teknologi dan perangkat secara online dan mobile, dimana akuisisi informasi terkait dengan kualitas dan harga, proses pencarian, ekspektasi konsumen berdampak pada cara kerja perusahaan. Akuisisi dan yang dipermudah dengan platforms/two-sided market. Teknologi digital ini mengubah secara radikal dalam konsumen berinteraksi di platform digital, baik dalm konteks WOM, online review and ratings, dan social media interactions. Perusahaan bisa meningkatkan kinerjanya dengan berkolaborasi dan memberi kesempatan kepada konsumen untuk saling berinteraksi dalam platform digital ini.

Bagi perusahaan, teknologi digital juga mengubah strategi pemasaran karena teknologi digital telah mengubah konsep produk dalam tiga cara: (1)menambah produk inti dengan layanan digital, (2)meningkatkan nilai tambah produk dengan membangun jejaring menggunakan teknologi digital, dan (3)mengubah produk menjadi layanan digital. Dengan demikian, perusahaan dapat menciptakan peluang dengan melakukan penyesuaian (customize) dan penawaran produk inti dan layanan 
JEMAP: Jurnal Ekonomi, Manajemen, Akuntansi, dan Perpajakan

ISSN: 2622-612X (Media Online) | Vol.4 | No.2 | Oktober 2021

tambahan yang bersifat personal secara digital. Strategi tailor offering semacam ini mensyaratkan pentingnya mengelola kebijakan harga dinamis, seperti lelang online atau penentuan harga mandiri (name-your-own-price strategies).

Demikian juga, bentuk komunikasi berubah dari pola tradisional seperti promosi di radio dan televisi menjadi sub channel yang menjadi bagian dari social channel seperti email dan mesin pencari (search engine) yang bisa membantu perusahaan memberikan nilai yang relevan dan signifikan sesuai keinginan konsumen yang terus berkembang (Ashley \& Tuten, 2015). Oleh karena itu, pemahaman tentang fungsi berbagai media/channel yang memberikan dampak yang berbeda akan memberi manfaat yang besar dalam menciptakan hasil dari teknologi digital.

Dalam hal ini perusahaan dapat melakukan riset pemasaran yang difokuskan untuk mengetahui bagaimana akuisisi dan proses pengolahan informasi dari penggunaan teknologi digital sebagai dasar dalam memilih strategi pemasaran yang memampukan perusahaan bisa menjaga keberlanjutan dalam persaingan. Faktor yang harus selalu diperhatikan dalam merumuskan strategi digital marketing adalah akses ke platform digital, memahami perilaku, karakteristik, dan profil pelanggan, kemampuan penggunaan fitur-fitur yang tersedia dalam platform dan jasa digital, serta layanan yang diharapkan pelanggan.

Dua elemen inti, yaitu keunggulan merek dan pengelolaan pelanggan yterus berubah di era digital maka perlu dikelola secara strategik. Pengetahuan tentang new channel, new shopping devices, dan new customer interactions call menjadi hal yang perlu selalu diperbarui sesuai perubahan. Memahami customer experience and customer engagement yang dipengaruhi oleh teknologi digital adalah upaya menjaga customer lifetime value.

\section{Cara dan Bentuk Digital Marketing}

Ada beberapa cara dan bentuk digital marketing seperti content marketing, social media marketing, PPC atau pay per click, email marketing, marketing automation, inbound marketing dan affiliate marketing. Content Marketing adalah semua format pemasaran yang meliputi pembuatan atau berbagi konten untuk 
JEMAP: Jurnal Ekonomi, Manajemen, Akuntansi, dan Perpajakan

ISSN: 2622-612X (Media Online) | Vol.4 | No.2 | Oktober 2021

tujuan menarik konsumen saat ini maupun konsumen potensial (Pulizzi \& Barrett, 2009). Biasanya konten ini disebarkan melalui berbagai media berbasis internet.

Social Media Marketing merupakan kegiatan pemasaran dengan menggunakan teknologi, saluran, dan perangkat lunak media sosial untuk menciptakan, mengkomunikasikan, menghantarkan dan pertukaran penawaran yang memiliki nilai bagi stakeholder perusahaan (Tuten \& Solomon, 2016). Manfaat yang diperoleh: meningkatkan kesadaran merek, mempengaruhi keinginan pembelian, mendorong percobaan produk, memudahkan pembelian bagi konsumen, dan mempererat kesetiaan merek.

PPC (Pay Per Click) and SEM (Search Engine Marketing). PPC merupakan bentuk pemasaran digital berbayar dimana pengiklan membayar biaya setiap kali iklan mereka di-klik. Istilah PPC dapat berlaku untuk iklan berbayar di jaringan media sosial, seperti Facebook, Twitter, dan LinkedIn (Burke, www.digitalmarketinginstitute.com). SEM merupakan sebuah bentuk dari pemasaran dunia maya yang mempromosikan website dengan meningkatkan kunjungan ke web tersebut melalui hasil pencarian melalui search engine (Tuten \& Solomon, 2016).

Email Marketing digunakan untuk mengirim file atau menghubungi seseorang untuk berbagai keperluan menggunakan email atau surel (surat elektronik), misalnya untuk melakukan kegiatan Customer Relationship Marketing (CRM). Marketing Automation adalah penggunaan perangkat lunak untuk mengotomatisasi proses pemasaran seperti segmentasi pelanggan, integrasi data pelanggan, dan manajemen kampanye (Todor, 2016) atau pengotomatisasian keputusan pemasaran dalam internet (Bucklin, et al., 2002). Inbound Marketing adalah bentuk pemasaran yang membutuhkan proses pemilihan target pasar yang sangat hati-hati dan menjalin komunikasi khusus melalui konten berkualitas tinggi (Patrutiu-Baltes, 2016). Beberapa bentuk Inbound Marketing diantaranya: topical blogs, social media campaigns, mailing campaigns, Search Engine Optimization (SEO), viral videos, web-based seminars (Webinars), dan lainnya.

Affiliate marketing adalah memberikan sistem komisi kepada seseorang yang berhasil merekomendasikan produk perusahaan kepada calon konsumen 
JEMAP: Jurnal Ekonomi, Manajemen, Akuntansi, dan Perpajakan

ISSN: 2622-612X (Media Online) | Vol.4 | No.2 | Oktober 2021

lainnya. Program afiliasi menawarkan biaya referensi afiliasi sebagai imbalan untuk mengarahkan pelanggan potensial ke situs web merchant. Afiliasi (pemasar yang menjalankan affiliate marketing) biasanya dibayar berdasarkan jumlah lead yang dikonversi oleh merchant menjadi pelanggan (pay-per-conversion) atau berdasarkan jumlah lead yang dirujuk ke merchant (pay-per-lead) (Libai, Biyalogorsky, \& Gerstner, 2003).

\section{METODE PENELITIAN}

\section{Gambaran Identitas dan Usaha Responden}

Mayoritas responden merupakan pengusaha yang relatif baru yang memulai usaha pada 2014 atau sesudahnya. Hanya 13,3\% pengusaha yang sudah memulai usaha sebelum 2014. Sebanyak 50\% responden memulai usaha online sejak berdiri. Hanya $16,7 \%$ yang memulai usahanya secara online beberapa tahun setelah beroperasi. Sebagian besar responden $(56,7 \%)$ merupakan penjual produk yang dibeli dari pihak lain dan hanya 26,7\% yang menjual produk yang diproduksi sendiri. Sisanya 16,6\% menjual produk yang dibeli dari pihak lain dan diproduksi sendiri (kombinasi).

Produk/jasa yang ditawarkan responden cukup bervariasi dan mencakup 36 jenis. Tiap responden rata-rata menawarkan 1-2 jenis produk dengan fashion sebagai produk yang ditawarkan oleh paling banyak responden $(44,4 \%)$. Jenis produk lain mencakup makanan $(13,9 \%)$, kosmetik $(11,1 \%)$, dan sisanya mencakup kebutuhan pribadi hingga kebutuhan hewan peliharaan. Alasan memilih menjual produk tersebut juga bervariasi, yaitu produk diminati/dibutuhkan konsumen $(22,5 \%)$, produk sesuai hobi (17,5\%), mudah mendapatkan penjual (12,5\%), dan alasan terkait dengan produk (seperti produk tahan lama, aman digunakan, memiliki kelebihan dibanding produk lain, mudah didapatkan, ada perbedaan, sudah djual turun temurun, dan harga terjangkau).

Produk dijual dengan atau tanpa modifikasi. Modifikasi produk dimaksudkan untuk menciptakan ciri khas pada produk, lebih menarik, menjaga kualitas, dan melindungi produk dari kerusakan pada saat pengiriman. Di sisi lain, 
JEMAP: Jurnal Ekonomi, Manajemen, Akuntansi, dan Perpajakan

ISSN: 2622-612X (Media Online) | Vol.4 | No.2 | Oktober 2021

produk tidak dimodifikasi antara lain karena produk sudah siap jual, membutuhkan waktu dan biaya modifikasi, dan sudah sesuai dengan foto yang ditampilkan online.

\section{Aktivitas digital marketing}

Aktivitas pemasaran online dilakukan melalui platform/marketplace/media online. Selain platform e-commerce (Shopee, Tokopedia, Bukalapak, Lazada), responden juga memilih media sosial seperti Facebook, WhatsApp, dan Line untuk melakukan pemasaran online. Terdapat tiga platform/marketplace/media online yang paling banyak digunakan oleh para responden untuk menawarkan produknya, yaitu Shopee (25,4\%), Tokopedia (22\%), dan Instagram (18,6\%). Alasan responden menggunakan platform-platform tersebut sangat beragam. Alasan yang dominan adalah platform tersebut banyak digunakan/dikunjungi/populer $(28,0 \%)$ dan adanya promosi yang ditawarkan oleh platform bersangkutan (13,3\%). Jangkauan yang luas, kemudahan penggunaan, keamanan, ragam layanan, dan tawaran-tawaran keringanan finansial merupakan alasan-alasan lain.

Responden menyampaikan ada lebih dari satu materi yang disampaikan dalam promosi. Product knowledge (61\%) dan promosi penjualan yang ditawarkan (22\%) menjadi materi terbanyak yang diinformasikan responden dalam platform. Materi lain terkait dengan hal-hal teknis, seperti informasi pemesanan, petunjuk pembelian, harga, iklan, dan testimoni. Materi ini disinyalir mendukung atau memperkuat materi utama tentang product knowledge. Adapun tujuan penyampaian informasi tersebut adalah untuk mempromosikan produk baru (22,4\%), mempengaruhi keinginan konsumen $(20,7 \%)$, menyesuaikan dengan program promosi dari platform/market place/media online (17,2\%). Sedangkan tujuan lain mencakup alasan memudahkan kegiatan pembelian (15,5\%), meningkatkan kesadaran merek $(13,8 \%)$, mendorong untuk mencoba $(5,2 \%)$, mempererat kesetiaan terhadap merek $(1,7 \%)$, dan mempererat hubungan dengan konsumen $(1,7 \%)$. Tujuan-tujuan tersebut dapat dikaitkan dengan tujuan mempengaruhi keinginan konsumen.

Pilihan layanan pengiriman barang merupakan keputusan penting dalam $e$ commerce. Penelitian ini mengungkapkan terdapat 15 usaha pengiriman barang yang terlibat dalam platform pemasaran online. Diantara usaha-usaha tersebut, JNE 
JEMAP: Jurnal Ekonomi, Manajemen, Akuntansi, dan Perpajakan

ISSN: 2622-612X (Media Online) | Vol.4 | No.2 | Oktober 2021

menjadi pilihan utama responden (19,5\%), disusul oleh J\&T (16,3\%) dan Si Cepat $(13,8 \%)$. Sedangkan TIKI yang lebih lama berdiri dibandingkan J\&T dan Si Cepat hanya dipilih oleh $8,1 \%$ responden. Walaupun Shopee paling banyak digunakan oleh responden, tetapi ShopeeExp hanya dipilih oleh 0,8\% responden. GoSend $(12,2 \%)$ dan Grab (7,3\%) menjadi pilihan untuk pengiriman lokal Semarang. Jasa pengiriman dipilih karena keberadaannya mudah dijangkau (20,9\%) dengan banyaknya counter/gerai yang tersedia, pengiriman cepat sampai (14\%), dan terpercaya/pasti sampai tujuan (14\%). Alasan lain yang disampaikan responden terkait dengan kepraktisan (banyak digunakan konsumen, 7\%; sesuai kebutuhan dan kemampuan konsumen, 7\%; mudah, 4,7\%), finansial (biaya kirim murah, 7\%; adanya promo, 4,7\%), dan kualitas layanan (jangkauan luas dan pelayanan bagus, masing-masing 4,7\%; aman dan nyaman, masing-masing 2,3\%).

Terkait dengan pilihan cara pembayaran, responden menyatakan 17 cara yang disajikan dalam kuesioner dipilih atau dipakai oleh konsumen dalam melakukan pembayaran transaksi. Transfer bank (25,5\%), COD (12,7\%), ShopeePay (10,8\%), dan pembayaran via toko ritel (Alfamart, Indomaret, Alfamidi, CircleK, FamilyMart; 8,8\%) merupakan cara pembayaran yang banyak digunakan oleh konsumen yang membeli produk responden. E-money belum banyak menjadi pilihan konsumen dan masih digunakan secara terbatas: OVO (7,8\%), Dana (3,9\%), LinkAja (2,9\%), dan GoPay (1\%).

Untuk menjaga hubungan baik dengan konsumen, responden juga mengelola keluhan konsumen yang muncul karena ketidakpuasan atas pelayanan yang diberikan. Namun 66,7\% menyatakan tidak pernah menerima keluhan Dengan kata lain, responden sudah mampu memenuhi harapan konsumen. Sedangkan keluhan yang diterima oleh $30 \%$ responden dapat dikelompokkan menjadi tiga, yaitu keluhan yang terkait dengan pengiriman, produk, dan komunikasi. Keluhan yang terkait dengan pengiriman mencakup lambatnya pengiriman $(34,3 \%)$ sehingga produk tidak sampai dalam waktu seperti yang diharapkan konsumen; barang tidak sampai dan diterima dalam keadaan rusak $(8,6 \%)$; barang tertukar/salah kirim $(5,7 \%)$. 
JEMAP: Jurnal Ekonomi, Manajemen, Akuntansi, dan Perpajakan

ISSN: 2622-612X (Media Online) | Vol.4 | No.2 | Oktober 2021

Keluhan-keluhan ini tidak terkait langsung dengan kinerja responden mengingat pengiriman dilakukan oleh pihak ketiga. Keluhan yang terkait dengan produk mencakup kemasan yang kurang bagus (2,9\%), kualitas bahan kurang baik $(2,9 \%)$, dan produk tidak sesuai harapan $(2,9 \%)$. Keluhan ini juga diluar kendali responden, mengingat bahwa sebagian besar responden hanya menjual kembali produk yang dibelinya dengan tanpa modifikasi. Keluhan yang terkait dengan komunikasi mencakup kesalahpahaman $(2,9 \%)$ dan produk tidak sesuai gambar $(2,9 \%)$. Kedua macam keluhan mengindikasikan bahwa responden kurang tepat dalam menyampaikan informasi atau gambar produk (yang hanya mementingkan segi keindahan) kepada konsumen sehingga menimbulkan interpretasi yang berbeda bagi konsumen yang mendorong terjadinya kesalahpahaman.

Cara yang paling banyak ditempuh responden dalam menangani keluhankeluhan konsumen adalah melakukan konfirmasi kepada usaha jasa pengiriman barang ke konsumen $(12,1 \%)$, memberikan insentif kepada konsumen dalam bentuk diskon atau bonus gift pada pembelian selanjutnya $(9,1 \%)$, mengembalikan uang konsumen yang sudah dibayarkan $(9,1 \%)$, dan menukar dengan produk lain $(3 \%)$. Sebagian responden juga berupaya memberi penjelasan seperlunya, baik terkait dengan masalah pengiriman maupun kondisi produk, merespon dengan baik dan sabar hingga minta maaf kepada konsumen atas ketidaknyamanan yang terjadi.

\section{Bentuk kegiatan digital marketing}

Terkait dengan bentuk kegiatan digital marketing, responden menggunakan lebih dari satu bentuk, namun social media merupakan bentuk yang paling popular di antara responden. Sebagian (50\%) melakukannya melalui social media, seperti Facebook, Twitter, dan LinkedIn. Ada 40,9\% responden yang menggunakan content marketing dengan menggunakan video, blogspot, maupun testimoni. Sisanya menggunakan affiliate marketing $(6,8 \%)$ dan PPC $(2,3 \%)$.

\section{Alasan melakukan kegiatan digital marketing}

Responden berpendapat bahwa pemasaran online memberikan keuntungan bagi mereka, yaitu biaya yang terjangkau $(6,3 \%)$, mudah menjangkau konsumen $(6,3 \%)$, dapat menjangkau lokasi yang jauh $(3,1 \%)$, mendapat keuntungan dari penggunaan online $(3,1 \%)$, metode yang semakin bervariasi $(3,1 \%)$, dan mudah 
JEMAP: Jurnal Ekonomi, Manajemen, Akuntansi, dan Perpajakan

ISSN: 2622-612X (Media Online) | Vol.4 | No.2 | Oktober 2021

dilakukan $(3,1 \%)$. Di sisi lain, responden juga merasakan adanya hambatan dan tantangan dalam melakukan pemasaran online, seperti persaingan yang semakin tinggi $(9,4 \%)$, perlu ketelitian dan kegigihan supaya produk dikenal $(3,1 \%)$, dan kesulitan membagi waktu untuk upload ke marketplace $(3,1 \%)$. Namun responden menyatakan akan melakukan upaya-upaya untuk mengatasi hambatan tersebut: tetap belajar untuk bisa memanfaatkan dan mendapatkan keuntungan dari pemasaran online $(9,4 \%)$, meningkatkan penanganan keluhan konsumen $(3,1 \%)$, berhadapan dengan konsumen yang tidak bertanggungjawab $(3,1 \%)$ responden. Responden juga menyatakan bahwa dengan pemasaran online mengandung kelemahan, dimana konsumen tidak bisa melihat produk secara langsung $(3,1 \%)$ dan penyampaian kualitas foto produk yang sangat tergantung pencahayaan $(3,1 \%)$. Kedua hal ini mungkin yang mendorong timbulnya masalah komunikasi yang menjadi keluhan konsumen.

\section{HASIL DAN PEMBAHASAN}

Kegiatan digital marketing oleh pengusaha dapat dikategorikan sebagai C2C dan B2C dimana responden yang sebagian besar merupakan individu dan sebagian kecil sebagai organisasi bisnis menjual produk yang dibeli dari pihak lain kepada konsumen akhir secara online, baik sejak awal berdiri usaha atau beberapa tahun kemudian setelah beroperasi. Sesuai dengan sifat kegiatan usahanya tersebut, sebagian besar responden menjual dengan tidak melakukan modifikasi atas produk yang ditawarkannya.

Aktifitas pemasaran yang dilakukan dengan menggunakan fasilitas digital (internet) mencakup semua proses transaksi, mulai dari promosi, pemesanan produk, pembayaran, hingga pengiriman produk ke pembeli. Responden menawarkan dan mempromosikan produknya secara online melalui dua platform: marketplace maupun media sosial. Marketplace yang paling banyak digunakan adalah Shopee dan Tokopedia, sedangkan media sosial yang populer digunakan adalah Instagram. Alasan yang mendasari pilihan atas platform yang digunakan bervariasi, namun yang dominan adalah karena platform tersebut banyak digunakan/dikunjungi konsumen dan ada promosi penjualan yang diberikan. 
JEMAP: Jurnal Ekonomi, Manajemen, Akuntansi, dan Perpajakan

ISSN: 2622-612X (Media Online) | Vol.4 | No.2 | Oktober 2021

Promosi bebas ongkos kirim yang dilakukan Shopee (Shopee, 2019b) dan inovasi yang selalu dilakukan Tokopedia yang memberi keuntungan bagi konsumen nampaknya menjadi daya tarik bagi konsumen maupun responden untuk memilih kedua platform tersebut sebagai tempat untuk transaksi online.

Dalam B2C, konsumen dapat secara aktif memilih site online dan mengontrol kontak tentang shopping apps yang akan digunakan dan informasi tentang suatu produk yang ingin diterima (Kotler \& Armstrong, 2014). Oleh karena itu, responden menyampaikan informasi tentang produk yang ditawarkan, katalog produk, dan promosi penjualan (diskon, free gift, gratis ongkos kirim) melalui platform yang digunakan. Instagram bisa menjadi alternatif media yang populer untuk menyampaikan informasi tersebut mengingat bahwa Instagram sangat sesuai dengan karakter dari sebagian besar produk-produk yang dijual (fashion, makanan, kosmetik) yang akan menarik bila ditampilkan dalam bentuk foto dan berbagi foto merupakan fokus dari Instagram.

Pada intinya, promosi yang dilakukan oleh responden tidak hanya terbatas pada memberi informasi, menciptakan minat tetapi juga mempengaruhi pembelian. Cara yang dilakukan adalah dengan mempromosikan produk baru, mempengaruhi keinginan pembelian, memanfaatkan promosi yang dilakukan oleh marketplace yang digunakan, serta memberikan informasi teknis tentang petunjuk pemesanan dan pembelian, harga, iklan, dan testimoni dalam bentuk foto maupun video.

Pengiriman produk yang dibeli konsumen diserahkan kepada perusahaan jasa pengiriman. Ada banyak macam jasa pengiriman yang ditawarkan dan kepraktisan (kemudahan dijangkau) menjadi alasan responden memilih menawarkan jasa pengiriman tersebut. Misal, JNE dan J\&T merupakan bisnis jasa pengiriman yang menggunakan sistem waralaba, sehingga keberadaannya yang mudah dijumpai memberikan kepraktisan dalam menggunakan jasa mereka. Selain kepraktisan, alasan lain adalah kehandalan dan kepercayaan yang dilihat dari kemampuan menyampaikan kiriman dengan cepat dan tepat serta dengan biaya yang terjangkau dan yang sesuai kebutuhan konsumen.

Menyediakan yang sesuai kebutuhan konsumen juga dilakukan dalam penyediaan cara pembayaran. Responden menawarkan banyak pilihan cara 
JEMAP: Jurnal Ekonomi, Manajemen, Akuntansi, dan Perpajakan

pembayaran yang ada secara online. Transfer bank, COD, ShopeePay, dan pembayaran via toko ritel merupakan alternatif cara pembayaran yang banyak digunakan oleh pembeli

Aktivitas digital marketing oleh responden nampaknya sudah memenuhi harapan konsumen, sehingga sebagian besar responden tidak pernah menerima keluhan dari konsumen. Keluhan yang muncul lebih terkait dengan masalah pengiriman yang berada di luar kendali responden, seperti pengiriman yang tidak cepat diterima, kiriman tidak sampai, atau diterima dalam keadaan. Oleh karena itu, tindakan yang diambil responden antara lain adalah melakukan konfirmasi kepada pihak jasa pengiriman, meyakinkan konsumen bahwa produk sudah dikirimkan, atau memberikan insentif atau bonus kepada konsumen.

Tabel 1. Implementasi Digital Marketing Pada Pengusaha

\begin{tabular}{|l|l|}
\hline \multicolumn{1}{|c|}{ Proses transaksi } & \multicolumn{1}{c|}{ Implementasi } \\
\hline Penyampaian Informasi atau & Media: \\
Pencarian Informasi & - Marketplace: Shopee \& Traveloka \\
& - Media sosial: Instragram \\
& Informasi yang disampaikan: \\
& - Product knowledge \\
& - Katalog produk \\
& - Promosi penjualan \\
& - Teknis pemesanan \& pembelian \\
& - Harga \\
& - Iklan \\
& - Testimoni \\
& - Promon penyampaian info: \\
& $-\quad$ Mempengaruhi keinginan beli \\
& - Memanfaatkan promosi marketplace \\
\hline Pemesanan produk & Mengikuti sistem yang berlaku pada marketplace \\
\hline Pembayaran & Menawarkan beberapa pilihan jenis pembayaran dari \\
& berbagai alternatif jasa pembayaran yang ada secara \\
& online: transfer bank, COD, ShopeePay, dan \\
& pembayaran via toko rite \\
\hline Pengiriman & Melalui perusahaan jasa pengiriman lain yang praktis, \\
& handal dan terpercaya \\
& Cepat \& murah \\
& Ada pilihan: JNE, J\&T, Si Cepat \\
\hline
\end{tabular}

Sumber: data primer yang diolah 2020

Sosial media seperti Facebook, Twitter, dan LinkedIn menjadi pilihan sebagian responden untuk melakukan promosi keberadaan usahanya. Sebagian lagi lebih memilih content marketing dengan menampilkan video atau testimoni atau membuat blogspot. 
JEMAP: Jurnal Ekonomi, Manajemen, Akuntansi, dan Perpajakan

ISSN: 2622-612X (Media Online) | Vol.4 | No.2 | Oktober 2021

Bagi responden, di satu sisi digital marketing dinilai mudah dilakukan, namun di sisi lain komunikasi menjadi hambatan karena gambaran produk sangat tergantung pada kualitas foto yang ditampilkan. Foto yang tidak baik dapat menimbulkan perbedaan gambaran produk di benak konsumen dengan yang diterima secara nyata dan hal ini bisa menimbulkan ketidakpuasan pada konsumen. Responden menyatakan akan terus belajar untuk mengurangi kelemahankelemahan ini dan akan terus menggunakan digital marketing karena perkembangannya yang semakin pesat ke masa depan.

Berdasar pengertian digital marketing menurut AMA dapat disimpulkan bahwa tingkat implementasi digital marketing oleh responden dapat dikatakan sudah cukup tinggi karena hanya mencakup pengkomunikasian dan penghantaran nilai kepada konsumen dan belum mencakup penciptaan nilai. Namun dapat dilihat bahwa pelaku usaha berupaya untuk bisa memberikan yang terbaik sesuai yang diinginkan konsumen, sehingga konsumen dapat melakukan proses transaksi online dengan nyaman, aman, dan mudah.

\section{PENUTUP}

\section{Kesimpulan}

Hasil menunjukkan bahwa implementasi digital marketing pada bisnis sudah cukup tinggi karena sudah mencakup promosi usaha, penyampaian informasi dan promosi tentang produk, fasilitas pemesanan produk dan pembayaran produk serta pengiriman produk. Namun sebagian besar menerapkan digital marketing hanya untuk proses penghantaran nilai melalui kegiatan menjual produk yang dibeli dari pihak lain kepada konsumen dan hanya sedikit yang melakukan penciptaan nilai (menghasilkan produk sendiri).

Aktivitas digital marketing dilakukan melalui lebih dari satu platform, antara lain marketplace (Shopee, Tokopedia, Lazada) dan/atau media sosial (seperti Instagram, Facebook, WhatsApp). Responden pengusaha memberikan banyak pilihan metode pembayaran dan pengiriman bagi konsumen. Sedangkan bentuk digital marketing yang dominan dipilih responden adalah social media marketing dan content marketing. Alasan yang mendasari menerapkan digital marketing 
JEMAP: Jurnal Ekonomi, Manajemen, Akuntansi, dan Perpajakan

ISSN: 2622-612X (Media Online) | Vol.4 | No.2 | Oktober 2021

adalah tren bisnis online yang memungkinkan menjalankan usaha dengan biaya yang relatif murah tetapi dengan jangkauan yang lebih luas.

\section{Rekomendasi}

Karena tingkat implementasi digital marketing sudah cukup tinggi, maka pengusaha dapat memperbaharui tingkat adopsi digital marketing sesuai dengan perkembangan teknologi internet yang terjadi. Misal, menambah penggunaan $e$ money yang semakin meningkat penggunaannya dalam pilihan metode pembayaran. Pengusaha juga dapat menambah pilihan jasa pengiriman baru yang menawarkan keunggulan dalam kecepatan pengiriman, keterjangkauan biaya, dan luasnya jangkauan wilayah yang dilayani. Disamping itu, adopsi teknologi juga harus diterapkan untuk bisa menampilkan gambar produk di media online secara akurat sesuai kondisi yang sebenarnya.

Hasil penelitian ini juga bisa memberikan gambaran tentang perilaku pembelian konsumen secara online yang berbeda dari perilaku pembelian konvensional. Secara teoritis, strategi pemasaran bagi pengusaha yang melakukan kegiatan digital marketing dapat dikembangkan dari perilaku pembelian online ini. Penelitian selanjutnya dapat dilakukan pada konteks yang berbeda untuk memperkaya pengetahuan tentang perilaku pembelian online.

\section{DAFTAR PUSTAKA}

American Marketing Association. (2019, September). Definitions of marketing. Diambil kembali dari American Marketing Association: https://www.ama.org/AboutAMA/Pages/Definition-of-Marketing.aspx

Ashley, C., \& Tuten, T. (2015). Creative strategies in social media marketing: An exploratory study of branded social content and consumer engagement. Psychology and Marketing, 32, 115-127.

Bucklin, R., Lattin, J., Ansari, A., Gupta, S., Bell, D., Coupey, E. Steckel, J. (2002). Choice and the internet: From clickstream to research stream. Mark Lett, 13(3):245-258.

Gunarto, R. I. (2019, Juli 26). Blog Fintek Media. Diambil kembali dari 10 pertanyaan manfaat digital marketing untuk bisnis ukm anda: http://fintekmedia.id/post/10-pertanyaan-manfaat-digital-marketinguntuk-bisnis-ukm-anda 
JEMAP: Jurnal Ekonomi, Manajemen, Akuntansi, dan Perpajakan

Kannan, P., \& Li, H. (2015). Digital Marketing: A framework, review and research agenda. Diambil kembali dari https://ssrn.com/abstract=3000712

Kotler, P., \& Armstrong, G. (2014). Principles of marketing, Fifteenth Edition. Essex, England: Pearson Education Limited.

Libai, B., Biyalogorsky, E., \& Gerstner, E. (2003). Setting Referral Fees in Affiliate Marketing. Journal of Service Research, 5(4), 303-315.

Neuman, W. L. (2004). basics of social research, qualitative and quantitative approaches. Boston: Pearson education, Inc.

Patrutiu-Baltes, L. (2016). Inbound marketing - the most important digital marketing strategy. bulletin of the transilvania University of Brasov Series V: Economic Sciences, Vol.9(58), No.2.

Pulizzi, J., \& Barrett, N. (2009). “Get content get customers”-turn prospects into buyers with content marketing. management case. Tata McGraw Hill Education Private Limited.

Shopee. (2019b). Apa Ketentuan Program Gratis Ongkir. Dipetik Juli 18, 2019, dari Shopee.co.id: https://help.shopee.co.id/s/article/Apa-ketentuanProgram-Gratis-Ongkir

Todor, R. D. (2016). Marketing Automation. Bulletin of the Transilvania University of Braşov Series V: Economic Sciences, Vol. 9(58) No.2.

Tuten, T. L., \& Solomon, M. R. (2016). Social media marketing. New Delhi: SAGE. 